\title{
The Rise and Fall of South African Venture Capital: A Coproduction Perspective
}

David Lingelbach, Villa Julie College and Johns Hopkins University School of Advanced International Studies (f-lingel@mail.vjc.edu)

Gordon C. Murray, School of Business and Economics, University of Exeter

(gmurray@exeter.ac.uk)

Evan Gilbert, Graduate School of Business, University of Cape Town (gilberte@gsb.uct.ac.za)

\section{Author Biographies}

David Lingelbach is an Assistant Professor of Business at Villa Julie College and a Professorial Lecturer at Johns Hopkins School of Advanced International Studies. His research interests are focused on entrepreneurship in developing countries, with a special interest in entrepreneurial finance.

Gordon Murray holds a Chair of Management (Entrepreneurship) in the School of Business and Economics at the University of Exeter. His research interests are focused on the genesis and growth of new knowledge based firms, early-stage venture finance, and international comparison of government policies towards enterprise.

Evan Gilbert is an Associate Professor in the Graduate School of Business at the University of Cape Town. His research is focused on capital budgeting techniques; futures, options, and other derivatives; investments; and real options. 


\begin{abstract}
An exploratory longitudinal case study of the South African venture capital (VC) industry is used to evaluate two perspectives on the VC emergence process. The first views VC emergence as the resolution of the simultaneity problem. We propose a second perspective, which sees emergence as the product of a teleological process involving coproduction between private sector fund managers and public sector investors. We develop process data from four sources: semi-structured interviews with current and past VC practitioners in South Africa, archival research at fund managers and newspapers, direct observation, and a review of relevant research. Our analysis shows the centrality of coproduction to the industry's emergence. These results suggest an alternative to the simultaneity model for explaining VC industry emergence in weak institutional environments.
\end{abstract}

\title{
Introduction
}

Venture capital (VC) is a key financial service required for the effective operation and growth of a modern market based economy. VC has been defined as "a professionally managed pool of capital that is invested in equity-linked securities of private ventures at various stages in their development" (Sahlman 1990). "Classic" VC is involved in the creation of new assets involving young firms often based on innovative technologies.

At present we do not have a very effective theoretical base for understanding how national VC industries develop, especially in weak institutional environments (WIEs) where regulatory barriers are high and property rights insecure (Desai 2006). New institutional economics argues that weak institutions are a major cause of the economic underdevelopment (North 1990) and may impede VC emergence. In addition, we do not yet clearly understand how policy environments and the interactions between government institutions and private sector parties either accelerate or retard VC industry development. Accordingly, the growth and subsequent stagnation of the VC industry in South Africa from 1980 to 2008 provides a potentially useful case study to aid our understanding of the emergence and evolution of VC industries in WIEs. 
The simultaneity explanation of VC emergence highlights the need for the simultaneous presence in sufficient quantities of three factors - pools of capital, specialized financial institutions, and entrepreneurs - to cause the industry to spring to life (Gilson 2003). However, the relative demise of the South African VC industry in the post-apartheid period-during which time all these factors were present - suggests that this explanation is not universal. We develop an alternative teleological narrative of the development of VC markets. This perspective also allows for an analysis of the role of government institutions and policies in the VC development process. It focuses attention on the concept of coproduction and its necessary presence for a VC industry to emerge and prosper.

We evaluate the effectiveness of these alternative explanations by presenting a summary and critical analysis of the evolution of the South African VC industry. We have collected data from four sources: semi-structured interviews with current and past VC practitioners in South Africa, archival research at fund managers and newspapers, direct observation, and a review of academic research. These data have allowed us to identify the changes in the levels and nature of coproduction in the post-apartheid period as a key reason behind the relative demise of the VC industry in South Africa. It also allows us to develop an integrated model of VC industry development pertinent to WIEs.

Our paper is laid out as follows. In the first section we present a review of the literature regarding the emergence of VC industries in WIEs. We explore two different narratives of emergence - the simultaneity and teleological approaches. Next we discuss our research methodology and data sources and then briefly outline the South African experience with respect to the development and demise of the VC industry. We follow with an analysis of the 
South African experience, analyzing the observed development path through the lenses of these two narratives. We identify the lack of coproduction in the policy attempts of the postapartheid South African government as a key reason for the demise of this industry in this period. We conclude that the two narratives are potentially compatible if coproduction is included as a necessary requirement for the facilitation of the development of the VC industry and suggest a possible model incorporating both narratives. Finally, we suggest implications for policy and future research.

\section{Literature Review}

Three research streams contribute to our current understanding of VC emergence: the management literature on VC, institutional theory, and economic sociology. Western VC is built on a series of strong assumptions about the institutional environment and economic actor behavior. These assumptions include 1) a belief in a rational, transparent and fair legal system in which contracts between economic actors can be enforced at a reasonable cost, 2) the contention that economic actors are generally motivated to pursue the maximization of their marginal utility function, and 3) an assertion that conflicts between investors (principals) and entrepreneurs or managers (agents) exist (Jensen and Meckling 1976) and can be largely resolved through incentive structures designed in VC contracts. Each of these assumptions is heroic in nature. It seems quite plausible, indeed likely, that many if not all of these assumptions could fail in the context of developing countries. ${ }^{1}$

Moreover, these (neoclassical economics) assumptions fail to offer an adequate explanation for the emergence of firms, groups, and industries from individual economic

\footnotetext{
${ }^{1}$ Developing countries can be defined as those economies identified by the World Bank as either low-income or middle income.
} 
behavior or to recognize the possibility that economic goals are usually pursued alongside other goals such as sociability, approval, status, and power (Granovetter 1992). Moreover, these assumptions admit no possibility that economic actors may pursue collective and altruistic interests alongside self-interested utility maximization (Van de Ven, Sapienza, and Villanueva 2007). Neoclassical assumptions require that new ventures create attractive risk adjusted returns (Gompers 1995, Pollock, Porac and Wade 2004). However, these assumptions are often relaxed in challenging early-stage contexts in Western Europe. Here VC industries and governments regularly seek policy initiatives that resolve conflict between, for example, economic return and desired innovation outcomes.

Based on these assumptions, several implicit narratives about VC emergence have been constructed to date. Narratives are stories that construct a credible, process-focused understanding about reality that is different from, but complementary to, logical-scientific knowledge (Bruner 1986, Eriksson and Kovalainen 2008, Van de Ven 2007). One narrative explains $V C$ emergence as a product of the VC cycle, in which fund managers raise capital from investors; invest, monitor, and add value to investees; exit investments; and raise new capital (Gompers and Lerner 2000). While the operation of this cycle is subject to a number of disruptive factors, including overinvestment in fashionable sectors and volatile exit market valuations, the underlying concept of the VC cycle is one of self-renewal and sustainable longrun growth.

A related narrative calls attention to the importance of the enabling conditions surrounding VC by highlighting the challenges associated with the initial establishment of the VC cycle. In this view, three factors - pools of capital, specialized financial institutions, and 
entrepreneurs-must be simultaneously present in sufficient quantities to cause a VC industry to emerge (Gilson 2003). As with the VC cycle, this simultaneity perspective is grounded in a life-cycle theory of social change, in which VC emerges organically in response to an underlying logic (Van de Ven and Poole 1995) or as the manifestation of an evolving agency relationship. A characteristic of life-cycle theories is that they prescribe a necessary sequence of events in order for development to occur (Jovanovic and MacDonald 1994, Vernon 1966, Van de Ven 2007). In the case of the VC cycle, fundraising logically precedes investment, which logically precedes monitoring, and so on. Most important from the standpoint of emergence, the logic of the VC cycle requires exits at attractive internal rates of return (IRRs) as a precondition for fund managers to raise their next fund, as well as the removal of failed investments in order to allow more time for potential successes (Gifford 1997). In the case of the simultaneity perspective, which we will argue can be seen as an antecedent to the first stage (fundraising) of the cycle, the life-cycle progression consists of multiple elements converging on the VC cycle's first stage (see Figure 1).

In the absence of a dominant theory of VC emergence, it is possible to construct a narrative about this process from perspectives already articulated by Gilson (2003) and Gompers and Lerner (2000). Gilson's simultaneity perspective provides the essential industry preconditions for the initiation and operation of Gompers and Lerner's VC cycle. This relationship is indicated in Figure 1.

While this sequence may provide an adequate explanation for VC emergence in economies with strong property rights, can this narrative account also for the emergence 
process in WIEs? On first inspection, very few of the active VC industries in these economies ${ }^{2}$ appear to have emerged organically as described by Gilson (2003). It seems possible that VC in these countries may emerge in distinctly different fashions than in the United States, Western Europe, and Japan. Evidence from a variety of developing and transitional economies, including India (Dossani and Kenney 2002), Hungary (Karsai, Wright, and Filatotchev 1997) and East Asia (Kenney and Han 2002), appears to support this line of reasoning.

A key finding from institutional theory is that cultural, political, and economic institutions play a central role in the success or failure of VC, but institutions are very slow to change. Institutional theory appears to explain the differing development trajectories for a variety of industries. VC is particularly sensitive to institutional environments given the very high levels of risk from a variety of sources involved in its operation. Legal origin is the most robust single measure of institutional effectiveness (for a discussion in the South African context see Brunt 2006), and countries seldom alter the legal origin basis of their political order. Countries with English legal origin are more likely to protect minority investors such as VCs (La Porta, Lopez-de-Silanes, Shleifer and Vishny 1998), and higher levels of VC exist in stock market-centered financial systems (Black and Gilson 1997). Yet, a number of WIEs possessing both of these features have inactive or nascent VC industries. This phenomenon has been interpreted as reflecting the simultaneity problem, i.e. the need for the simultaneous presence of capital, specialized financial institutions, and entrepreneurs (Gilson 2003).

\footnotetext{
${ }^{2}$ Using the presence of a national VC association as one possible indicator of an active (or aspirations for a) VC sector (Kenney, Haemmig, and Goe 2007), 16 developing countries or regions have such sectors at present. Another possible indicator is the presence of legislation specifically targeted at the VC sector, such as tax incentives.
} 
However, the simultaneity perspective does not explain the emergence of the South African VC industry from the 1980 to the present. Where this national VC industry once emerged and was active, it is now declining-in spite of the simultaneity problem having been largely solved. Despite significant local pools of capital (approximately 48,000 USD millionaires and large pension and insurance industries), a diversity of established VC organizations, high levels of opportunity entrepreneurship comparable to economies with established VC industries (such as Sweden), and active state involvement in VC development, the country's VC industry appears to be submerging after an initial period of growth. The question as to why this has occurred is of both theoretical and practical importance.

While VC has been studied to date mainly through an economic lens, in many WIEs VC appears to emerge in the muddled borderlands between the market and the state. Thus, VC may be shaped by broader societal and institutional forces that can more productively be addressed through theoretical frameworks from other disciplines, such as economic sociology. Social capital theory may especially offer an alternative approach to understanding factors driving the emergence of VC industries, particularly in WIEs.

Social capital-i.e. the norms and networks that enable people to act collectively-plays a significant role in facilitating both nascent entrepreneurs and startups (Davidsson and Honig 2003). New organizational populations (such as national VC industries) are more likely to emerge when founders pursue sociopolitical strategies that enhance their moral and regulatory legitimacy (Aldrich and Ruef 2006). Many of these strategies are associated with social capital building at various levels of analysis. Of the principal approaches to social capital, it has been shown that synergy - the mutual reinforcement of effective state institutions and civic 
engagement-can contribute to economic development (Evans 1996). Amongst the various perspectives on social capital, the link between synergy and economic development is also most broadly supported by empirical research (Woolcock and Narayan 2000).

Cooperative relations between the state and society can be divided into two phenomena: complementary actions by the state (such as the rule of law), and embedded relations connecting actors in the public and private sectors (Evans 1996). Synergy appears to be created when both complementarity and embeddedness are present (Lam 1996). While the importance of complementary state activities is widely acknowledged in the institutional and VC literatures (e.g., Lerner, Moore, and Shepherd 2005), embedded relations between VCs and state actors have not been studied to date. Understanding the structure of synergy between government institutions and fund managers may help us to better understand how VC emerges and, as is the case in South Africa, what causes its subsequent demise. One intriguing indicator of the level of social capital in the South African VC industry is the low level of private equity syndication in comparison to the US and Europe (Bent, Williams, and Gilbert 2004).

Coproduction is one specific means by which synergy between the public and private sectors can arise (Ostrom 1996). When inputs from these sectors are complementary, synergy can occur. Coproduction describes a process in which inputs from individuals in different organizations are transformed into goods or services (Ostrom 1996). To the extent that the "equity gap" is filled mainly by public VC (HM Treasury and Small Business Service 2003, Maula 
and Murray 2003, Maula, Murray, and Jääskeläinen 2007), coproduction offers a model through which this process of developing a country's VC industry can also be examined. ${ }^{3}$

The use of the concept of coproduction introduces the possibility of a process theory to VC emergence that is fundamentally different from, but perhaps complementary to, the lifecycle based theories of the VC cycle and simultaneity. Teleological theories are based on the notion that "purpose or goal is the final cause for guiding movement of an entity" (Van de Ven and Poole 1995). Instead of following a prescribed event sequence, teleological processes are adaptive and accommodative of creativity. They recognize that many paths to the same end state may exist. These types of processes consist of four activities: goal formulation, implementation, evaluation/dissatisfaction, and search/modification. In as much as coproduction must be purposefully constructed between public and private actors, any change process that relies on coproduction becomes in essence purposeful and hence teleological. In contrast, life cycles tend to be deterministic and prescriptive with a number of given and sequential states through which the 'subject' passes over time.

\section{Coproducing Venture Capital}

"If I want to raise a second fund here in South Africa, I will need to give away $25 \%$ of my fund management company to a black economic empowerment partner."-a white South African VC fund manager, August 2007

\footnotetext{
3 Public venture capital can be defined as "(government) programs that make equity or equity-like investments in young firms, or encourage other intermediaries to make such investments" (Lerner 2002). These programs can be "either directly operated or controlled by the government, or indirectly subsidized through the use of tax incentives" (Armour and Cumming 2003).
} 
In coproduction processes "regular" and "consumer" producers depend on one another, and each possesses resources and/or capabilities that cannot be completely substituted for one another (Lam 1996). In the case of VC emergence, since governments are frequently the major (and often the only) source of seed and early stage equity finance for young innovative firms, governments can be seen as "regular" producers. On the other hand, private sector VC fund managers are users of the capital provided by government and can be seen as "consumer" producers in the VC emergence process possessing specialized commercial skills that government investors lack. Government investors and private fund managers depend on each other to provide key components-capital and skills-of the VC process. In recognition of the "equity gap," such "hybrid" funds have become an increasingly important part of VC industries in OECD countries (Thompson and Choi 2002).

Embeddedness refers to "ties that cross the public-private divide" (Evans 1996). While originally studied in the context of relations between the state and relatively powerless citizens, embeddedness may be even more common in relationships between the public sector and elite actors (Evans 1996), such as VC fund managers. How do we recognize the existence of embeddedness? Two examples from Africa-one successful, the other not- may suffice. In Lesotho a rural credit union program impacted approximately 200,000 individuals through strong support from the government, committed grassroots organizations (who formed and managed the credit unions), and strong support from a local non-governmental organization (NGO) - a university. Strong linkages amongst all of these actors and the ability of grassroots organizations to influence government policy at a key juncture played roles in the success of the program (Brown and Ashman 1996). By contrast, in Nigeria public officials discouraged 
contributions by parents to primary education programs, thus preventing coproduction.

Governmental takeovers of schools perceived by parents as their own, disruptive changes in the systems for funding and running primary schools, and top-down decision making by education officials contributed to an atmosphere of distrust that stymied cooperation (Ostrom 1996).

In the South African context in which VC has tried to emerge, evidence of embeddedness could be seen in direct involvement of government investors that extends beyond contractual requirements, such as board meeting attendance; and the presence of dense social networks between governmental investors and fund managers. There can be little doubt that the collapse of apartheid has had a profound general impact on the nature of social relations between various elements of South African society, most notably between the majority black African and minority white populations. Our proposition is that embeddedness has been weakened by the changes of the post-apartheid era, and that such weakened embeddedness has made more difficult the emergence of VC in South Africa.

Weakening embeddedness in post-apartheid South Africa reflects in part the emergence of a black African government and related new economic elite, contrasted with a VC industry that has remained mainly white and European in its character and expertise. While many VCs remain strongly committed to the social and political objectives of the post-apartheid government, linkages of trust have been slow to form between government investors (mainly represented at the working level by whites) and fund managers (mainly white). Lack of trust has complicated and slowed the creation of altruism between the government and fund managers that could have sped the emergence and increased the probability of the VC industry's sustainability. 
Specifically, we suggest that:

Proposition 1: VC emergence in WIEs is in part a teleological process. Purposeful social construction by both government investors and fund managers is required to initiate and, in some instances, maintain the "VC cycle."

Proposition 2: Coproduction and embeddedness are the central elements in the teleological process that forms part of VC emergence. Specifically, government investors and fund managers coproduce VC in part by forming and maintaining embedded relations with each other; these relations are motivated by both selfish and altruistic motives.

Proposition 3: Embeddedness is a precondition for coproduction in VC emergence. Proposition 4: A decrease in coproduction (due to weakening embeddedness) between government investors and fund managers in South Africa during the post-apartheid era has led to an inability of the VC industry to emerge and become self-sustaining.

\section{Research Methodology}

To examine these questions, we use an "alternatives templates" strategy (Langley 1999) to compare the simultaneity/VC cycle (life cycle) and coproduction (teleological) models. In the spirit of Allison (1971), we recognize the possibility, indeed the likelihood, that this comparison will result in a composite model of VC emergence incorporating aspects of both models. We develop process data from four sources: semi-structured interviews with current and past VC practitioners in South Africa, archival research at fund managers and newspapers, direct observation, and a review of the limited academic literature on the South African VC industry. Fifteen interviews were conducted over the period July 2007-January 2008 and included 
executive management at VC funds, government organizations investing in VC funds, the national VC association, academics researching VC or entrepreneurship, and entrepreneurs receiving VC investment. We interviewed all of the government organizations currently involved in VC as investors or fund managers, three fund managers that have received funding from public sources (national, regional, and DFI), and one fund manager with exclusively private investors. Our interviews including a one week extended interview with and observation of a fund manager which received $50 \%$ of its funds from public sources. This fund manager was selected due to the access it provided to additional data-including interviews with investees, board minutes, and other documents-with which to confirm or disconfirm data from other sources. These interviews examined the presence or absence of a teleological process in South African VC emergence, how coproduction and embeddedness between public and private VC actors has changed over time (if at all), and the determinants of those changes.

Following each interview, a transcript was prepared, based on extensive notes taken by the lead author during each session. On the basis of this transcript an "incidents list" was created before being assembled into events. These events formed the core data used to develop a narrative of the VC emergence process.

\section{The Emergence of South African Venture Capital}

"South Africa in the eighteenth century had already learned to depend, as it depended so remarkably in the nineteenth and twentieth centuries, upon windfalls for its prosperity." C.W. De Kiewiet, A History of South Africa Social \& Economic (1941)

Economic growth and job creation have remained elusive in South Africa. At 1.2 percent per annum from 1994 to 2004, per capita GDP growth in South Africa is equivalent to that in sub-Saharan Africa (1.1 percent) or Latin America (0.8 percent). South Africa began to de- 
industrialize beginning in the mid-1980s due to a decline in the relative profitability of manufacturing. This change in its economic structure has been the principal source of its underperformance (Rodrik 2006).

Beginning in the late 1980 s and continuing to the present time, successive South African governments have struggled to address this underperformance using a variety of policy instruments. Post-apartheid macroeconomic stabilization policies have been largely effective (OECD 2006). As a result, the policy emphasis has increasingly shifted to innovation policy as a principal means to improve the country's export-oriented manufacturing sectors. While national innovation policies have a number of elements, VC development has been an important component in South Africa's search for a more robust and sustainable innovation program. This program is one element in the country's efforts to increase the low levels of investment that the government judged to be a principal reason behind slower than expected GDP growth after 1994 (Hirsch 2005).

Widespread interest in VC began in the mid-1980s with the establishment of the Johannesburg Venture Capital Club (JVCC). JVCC was spearheaded by a partner of a local accounting firm, who had visited the United States and seen business plan presentations to VC clubs. Although local law firms, private equity managers, the Industrial Development Corporation (IDC), and Business Partners all participated in JVCC, the effort died out by 1990. Interest in VC did not translate into the establishment of the country's first formal VC fund until 1992, when Technifin was founded. A joint venture between two state-controlled organizations, IDC and the Council of Scientific and Industrial Research (CSIR), Technifin focused 
on commercialization of technologies, based in part on the previous success of CSIR in licensing lithium battery technology.

The evolution of VC in South Africa is intertwined with small and medium enterprise (SME) development, which has in turn become linked closely with black economic empowerment $(B E E)^{4}$ in the post-apartheid era. While the National Party began showing interest in small business development for Afrikaners as early as the late 1930s, the first modern initiatives in SME development occurred in 1979, when the Carlton Conference (a business forum) and then-Prime Minister P.W. Botha recognized the importance of small business, including for black Africans, coloreds, and Indians in urban areas.

High levels of ownership and market concentration in many sectors developed during apartheid's late period and severely limited the ability of new, innovative, and entrepreneurial firms to emerge, particularly amongst the majority black African community. SME development became a key policy priority for the African National Congress (ANC) after it gained power in 1994, reflecting the party's view that the economy was dominated by white-owned conglomerates (Hirsch 2005). A Presidential Conference on Small Business in March 1995 produced a "White Paper on National Strategy for the Development and Promotion of Small Business in South Africa", which in turn led to the establishment of four institutions focused on promoting small business development, including one new financial intermediary--Khula Enterprise Finance (Khula) - dedicated to providing SME finance.

The government's SME development policies were part of its larger economic policies, of which GEAR (Growth, Employment and Redistribution: A Macro-Economic Strategy) was the

\footnotetext{
${ }^{4}$ Black economic empowerment is a broad initiative of the South African government that focuses on improving the economic prospects of previously disadvantaged populations.
} 
most important during the period 1996-2000. GEAR focused on greater fiscal prudence, easing monetary policy, and private investment encouragement as its principal pillars (Hirsch 2005), with objectives including faster growth, employment creation, and reduced inflation. However, despite tight coordination across ministries, and between the government and the Reserve Bank (at least at the outset), GEAR's impact was limited. Tight monetary policy, crises in other emerging markets in 1998, reduced government investment due to tight fiscal policy, and cautious private sector behavior all played a role in the resultant disappointing economic and employment growth. The high real interest rates that resulted from GEAR's incomplete implementation also reduced the attractiveness of private equity and VC as investments, along with all long-term investments.

The evolution of the South African private equity and VC industries during the period 2000-6 is indicated by the data in Table 1.

\section{Alternative Templates: Simultaneity and Coproduction}

We find strong evidence that coproduction and embeddedness between governmental investors and private VC fund managers have weakened in the post-apartheid era. While early efforts at VC emergence, such as the creation of the Small Business Development Corporation (SBDC) in the late 1970s, involved intimate involvement between private and public sector actors, post-apartheid attempts at VC emergence show evidence of a growing distance between public and private sector actors.

Two events seem of critical importance to the dilution of embeddedness between government investors and fund managers - the 1999 "jumpstart" of the industry spearheaded by IDC, and the efforts, beginning in 2003 , to promote a BEE program at the national level. 
IDC's first round of VC fund investing appears to have been driven by a top-down commitment to developing South Africa's innovation capacity. This commitment was articulated by the Department of Trade and Industry (DTI), but was ultimately a product of the economic policymakers of the Mbeki administration. Based on interviews with fund managers active at that time, no evidence exists that fund managers were actively consulted as this policy was drafted. This lack of active consultation may be due to a variety of factors, including the autocratic nature of the Mbeki administration (Gumede 2005).

The design and implementation of the 1999 IDC program also reflected the weak embedded relations between IDC and the funds in which it invested. IDC officials expressed general disappointment with these funds' performance, commenting that 1) none of the initial funds in which they invested were able to raise the levels of total capital expected at the time of their commitment and 2) all were past their deadlines for reaching full investment. In part as a result of IDC's disappointment with these funds, and rather than seeking to understand the sources of underperformance or the perspective of the fund managers, IDC decided to establish a direct investment program, placing it in competition with the funds that they helped establish.

Fund managers also appeared to make little effort to strengthen their embedded ties with government investors in the post-apartheid era. One fund manager expressed resentment that IDC's investment added no value to its initial fund-raising efforts, as it did not catalyze other investment in the fund. In testimony before the Parliament's Committee on Science and Technology concerning the establishment of a Technology Innovation Agency, a South African fund manager stated that "(t)ypically, Government Agencies do not have the capacity to fulfill 
this role of value-add investor and from our experience with the BRICs (N.B.-Biotechnology Regional Innovation Centers), their personnel do not have the expertise, networks or time to perform these functions" (Sherwin 2008).

These post-apartheid era views can be contrasted with the embedded relations between public and private sector actors concerned with VC in apartheid-era South Africa. Anton Rupert, a leading Afrikaner entrepreneur and founder of Richemont and the Rembrandt Group, formed a close relationship with the highest levels of government during that era, which was central to the establishment of SBDC (Dommisse 2005).

In what ways, if any, does the VC emergence process in South Africa resemble a teleological model of social change? As noted earlier, teleological models consist of four stages-goal formulation, implementation, evaluation, and modification-which are not necessarily sequential (see Figure 2 for an indicative illustration). The motor of change is purposeful social construction, while change takes place constructively at the level of a single entity.

\section{Goal formulation}

The formulation of goals related to VC emergence in South Africa has taken place largely in the context of the country's post-apartheid political economy. The focus of the ruling ANC has been on macroeconomic stabilization, given the fragile state of the economy inherited from the apartheid-era government. Predating these concerns, however, has been the historic commitment of prior governments to industrial development, which can be seen clearly in the establishment of IDC in 1940. 
In examining the goals related to VC development, one underlying theme has been the dialectical conflict between the goals of job creation and innovation. This ongoing confrontation has failed to generate a synthesis to date. As in many other countries, VC development in South Africa has not been a direct goal in itself, but, instead, has been linked to other economic and social goals. This linkage first emerged in the late 1970s, when the objective of job creation for both black Africans and whites played an important role in the establishment of the SBDC. Government encouragement of entrepreneurship-and the related interest in stimulating VC-reflected the structural break experienced by the South African economy linked to the decline of gold mining (Feinstein 2005). The introduction of international sanctions in the mid 1980s led to a second, temporary goal of import substitution, which played some role in the establishment of the private equity industry but appears to have a limited impact on entrepreneurship and VC. One informant indicated that, while sanctions could have created demand for locally produced products and hence stimulated entrepreneurship, most potential entrepreneurs and their financiers sensed that the opportunity presented by sanctions would not last very long.

Innovation emerged as a goal directly linked to VC in the late 1980s, although government interest in this goal can be traced to the 1962 establishment of the South African Inventions Development Corporation (SAIDCOR) as a division of CSIR. Several informants described South Africa's innovation capacity as being "mid level" and focused primarily on applications. A key economic policy maker stated that "in general, South African manufacturing firms had no reputation for genuine product innovation" but also noted apartheid-era innovations in areas such as oil from coal, nuclear power, military specification electronics, 
communications technologies, and systems integration capabilities (Hirsch 2005). Two important industrial innovations - lithium batteries and RFID tags-emerged from these efforts, while one significant process innovation-human-to-human heart transplants-was pioneered in the country.

The first implementation of innovation as a goal related to VC occurred in 1988, when IDC and SAIDCOR formed Technifin, the primary purpose of which was technology commercialization. After making four investments, Technifin ceased operations in 1993-4, and IDC transferred its ownership to SAIDCOR.

After Technifin's failure, innovation faded as a goal until the late 1990s, when it reemerged in the wake of the government's 1996 white paper on science and technology. This document described a national system of innovation, but, as one informant noted, South Africa lacked an integrated national innovation policy as of mid 2007. A national research and development (R\&D) strategy was announced in 2001, as well as strategies for advanced manufacturing and biotechnology.

The drafting of a national VC program by DTI in 1999 was directly linked to the government's efforts to spur innovation, according to several informants. Perhaps reflecting the collective nature of the ANC leadership, no informant could point to a national-level champion for this effort; innovation policy was reported by informants as simply one element of economic policy.

The final report to DTI on the national VC program made four recommendations, which articulated for the first time goals related to VC development in South Africa: 
1. Development and maintenance of a VC infrastructure, including education and business support;

2. Encouragement of and assistance to entrepreneurs, including a network of facilities, workshops, and mentorship;

3. Direction of Government-supported research and development, including rationalization of programs across departments, earmarking of $20 \%$ of parliamentary funding to be matched with private funding, allocation of R\&D funding for SME benefit, and tax concessions, and;

4. Increased availability of seed and early stage capital through the establishment of five VC funds modeled on the Australian Innovation Investment Fund (IIF) program, the development of private capital sources, and the encouragement of an active angel network (Stillman, Sunderland, Heyl, and Swart 1999).

The increasing emphasis on innovation and VC development in the late 1990s was underpinned by the growing emphasis by Presidents Mandela and Mbeki on economic growth, which can be dated almost from the beginning of Mandela's presidency in 1994. In addition, at the level of VC fund managers, the goal of catching the next technological wave began to emerge in the late 1990s during the later stages of the global dot.com boom.

By 2003 another wave of goal formulation developed, focused once again on job creation, particularly for unskilled black African workers. South Africa's subpar economic growth and a changing economic structure that was shedding unskilled jobs heightened concern amongst policymakers that the benefits of "the rainbow nation" were not being shared equitably. BEE and a related initiative, broad-based black economic empowerment (BBBEE), 
sought to increase black African participation in the economy through targeted ownership and employment percentages. The VC industry was able to manage the impact of BEE and BBBEE on its investees and fund managers through the more relaxed BEE/BBBEE requirements for small business, as well the inclusion of VC investments as BEE-qualifying for ownership quotas.

$\mathrm{BEE} / \mathrm{BBBEE}$ heralded the return of the tension between innovation and job creation goals which has characterized VC emergence in South Africa since the late 1980s. This tension and the formulation of goals across both the apartheid and post-apartheid eras are the most distinctive attributes of the VC goal formulation process in South Africa.

\section{Implementation}

The unresolved conflict between the goals of innovation and job creation has had an impact on the implementation of those goals as a part of the VC emergence process. The implementation portion of the emergence process can be divided into two historical phases: pre-1999, where SBDC/Business Partners and Technifin were the principal initiatives, and post1999, where IDC was the key driver of VC development.

Technifin and Business Partners represent fundamentally different approaches to implementation of VC-related goals. Established in 1980 as SBDC, Business Partners focuses on providing a range of financial and property services to the SME sector in South Africa and elsewhere in southern and east Africa. Currently $20 \%$ owned by the South African government via Khula, Business Partners has had a long-standing interest in VC and private equity, although the bulk of its activities consist of debt finance to established, lifestyle SMEs. Its business model emphasizes providing a mix of debt, equity, quasi-equity, and real estate products, which can be tailored to meet the specific requirements of its clients. 
Following the establishment of formal goals and recommendations for VC development in late 1999, IDC was directed by DTI to implement the recommendation concerning the establishment of new VC funds. However, it was clear from the outset that the design of IDC's VC fund program varied from that proposed in the recommendations made in the report on VC to DTI in 1999 (Stillman, Sunderland, Heyl, and Swart 1999). In particular, the IDC did not provide incentives to private investors to invest in these funds; IDC's investment was pari passu with private investors, and its returns were not capped. Table 2 indicates those VC funds in which IDC invested.

IDC investments in VC funds took place in two phases: $2000-1$ and post-2001. A key difference between the two phases is the shift from technology-oriented funds in the former to more generalist investment strategies in the latter. This shift does not appear to have been made with the benefit of any formal evaluation of the performance of the funds in the first phase.

While IDC's fund investments were the principal efforts directed at VC implementation, other VC funds were established primarily with private sector capital, including Ethos' Tech Fund I (Rand 270 million in capital under management, established 2001-2) and HBD Fund I (Rand 70 million under management, established 2000). Both funds focused on early-stage technology firms, although Ethos preferred businesses with existing revenues.

\section{Evaluation}

Despite dissatisfaction with the overall implementation of VC, limited formal evaluation of the industry has occurred to date. However, much informal evaluation of VC was provided by informants, indicating that this activity within a teleological process has occurred. The two 
known instances of formal evaluation are IDC's 2006-7 self-study of its experience with VC fund investment, and the industry association's 2008 draft white paper on proposed changes in regulations impacting VC investment.

IDC's self-study examined other models of VC investing, including the experiences of the International Finance Corporation (IFC), 3i, Commonwealth Development Corporation (CDC), and Enterprise Ireland. IDC concluded that it had learned enough from its fund investing experience to shift to direct investing. This conclusion was notable for differing with mainstream academic and practitioner views on public VC, which emphasized public-private partnerships in which government plays the role of a passive investor with capped returns.

The Southern African Venture Capital and Private Equity Association's (SAVCA) evaluation of the industry has taken the form of a draft white paper on VC development. To date, the industry association has focused on regulatory changes, such as tax treatment of capital gains (favorable changes in which were included in the government's 2008 budget speech) and exchange controls, rather than on the goals associated with VC, the implementation of these goals by fund managers and investors to date, or a formal evaluation of goals and/or implementation. Informants have indicated a growing recognition of the importance of strengthening embeddedness between government actors and fund managers, including the need for a forum for dialogue with the National Treasury and improved linkages with government actors concerned with innovation policy.

Informal evaluation of South Africa's experience with VC to date is widespread amongst the key stakeholders in the industry. Informant reports about evaluation have generally focused on implementation issues and the broader enabling environment, rather than on goal 
formulation and the unresolved tension between innovation and job creation. Regulatory constraints (including those limiting exit liquidity), political distortions impacting fund managers (including BEE/BBBEE, government investor micromanagement, and the concentration of early stage capital in the hands of government investors) and deal flow issues were most frequently cited by informants in their evaluation.

\section{Modification}

Despite limited formal evaluations, significant modifications have been made to the implementation of VC in South Africa. However, the tension between innovation and job creation goals has remained unresolved to date, and both goals remain central to VC development.

Specific modifications to VC implementation include 1) IDC's shift from funds to direct investing, 2) the impact of BEE on future fund-raising efforts, including the need to alter fund management company ownership in order to raise local funds, 3) Blue Catalyst's (a regional

fund established by the Gauteng provincial government) shift away from VC to networking, 4) the shift to later stage investing by early stage VC funds and the discontinuation of some earlystage funds, and 5) the Innovation Fund's shift to commercialization and IP protection.

\section{Life-cycle models of VC development}

The current narrative of $\mathrm{VC}$ emergence can be seen as two linked life-cycle processes of change, as indicated in Figure 1. How well does this model describe the process of VC emergence in South Africa? With respect to the simultaneity conditions precedent to the VC cycle, informants have reported that each of these conditions is present in sufficient quantities to stimulate the VC cycle. In particular: 
- Pools of capital-South Africa is notable for its large number of US dollar millionaires, estimated at 48,586 in 2007 (Capgemini and Merrill Lynch 2007). Informants also report evidence of local entrepreneurs investing as angels or VCs in start-up or early-stage firms. In addition, large pools of capital are controlled by government and private sector pension funds;

- Specialized financial institutions-Informants report no barriers to the establishment of VC funds or fund management organizations, including legal forms conferring limited liability on investors. The regular establishment of VC funds since the late 1990s confirms that specialized financial institutions can operate in the South African environment.

- Entrepreneurs-While general studies of South African entrepreneurship indicate a paucity of opportunity-oriented activity (Maas and Herrington 2007), informants report sufficient deal flow to operate VC funds. For example, one technology fund manager reported that it invested in $2.1 \%$ of the deals it saw, roughly equivalent to metrics of VC funds in other markets.

Given that simultaneity conditions appear to have been satisfied in South Africa, has the subsequent VC cycle come into operation? Informants indicated that as of mid 2007, the VC cycle appears to be incomplete as viewed across the industry as a whole. In particular, in some instances fund managers have raised second funds without securing exits from investments made in earlier funds at attractive IRRs. In most cases, these second funds have been raised in part by altering significantly the investment strategy. For example, one informant secured commitments from investors for a second fund by broadening its investment strategy beyond 
South Africa and the specific technology domain of its first fund. Another fund manager altered its investment strategy to focus on later stage transactions.

Do the life cycle-based models of VC emerge give a better account of VC emergence in South Africa than a teleological model? Based on the current, incomplete evidence, while the underlying logic of the simultaneity/VC cycle model appears to be present in the day-to-day operations of individual funds (particularly in the stages from fundraising to monitoring and adding value), the sequence of events associated with VC emergence in South Africa also seem consistent with a teleological model, in which events did not seem to proceed in a necessary order, but included many unresolved conflicts (such as that between job creation and innovation in the goal formulation process), dead ends (such as the failure of Technifin), and ad hoc adaptations in the absence of formal objective evaluations (such as IDC's shift to direct investing). We turn now to consider what role, if any, coproduction may have played in a teleological narrative of VC emergence in South Africa.

A key difference between life cycle and teleological processes of change is that the latter does not prescribe a necessary sequence of events (Van de Ven and Poole 1995). If VC emerged in South Africa in a sequence of events that varies from that seen elsewhere, then this narrative may suggest that the VC emergence process has a teleological element. More particularly, if purposeful coproduction of VC in South Africa took place between government investors and fund managers, and if that particular sequence of events varies from VC coproduction processes elsewhere, we can conclude that the role of coproduction is important in the evolution of a country's VC industry. 


\section{Evidence on coproduction}

As noted earlier, we suspect that coproduction may be a central component in any teleological process of VC emergence. In this narrative, coproduction is socially constructed by the government and fund managers, both of which are interested in the emergence of an active VC industry. From the government's standpoint, the primary interest is in filling the "equity gap" that appears to exist for seed and early stage investments in young innovative firms, while fund managers have an interest in securing patient (and cheaper) capital, usually unavailable from private sources, that can serve as the basis for developing the track record required to raise the next fund.

Evidence for attempts at coproduction in the South African VC industry can be seen by examining cooperation between government and fund managers at three levels: policy changes, modifications to existing goals and implementation, and day-to-day operations. At the level of policy change, the contrast can be drawn between Anton Rupert's intimate involvement with government in the development of SBDC in the late 1970s and early 1980s, and, as indicated by informants, the more modest efforts of SAVCA to change regulations having an adverse impact on VC exits in 2007-8. South Africa's experience in this regard can be contrasted with that of the UK, where Ronald Cohen and David Cooksey have advised government on public VC policy as powerful insiders. South Africa has lacked such gurus to date.

At the level of changes to the goals and implementation of existing VC programs, informants indicated a contrast between fund managers having had little direct impact on IDC's programs, while playing a more significant role in altering regional programs, such as Blue 
Catalyst. At the level of day-to-day operations involving funds in which IDC has invested, informants indicated a steadily deteriorating situation characterized by micromanagement, slow decision-making, and marginal contributions to private fundraising of government investment. This narrative suggests that, while coproduction between government and fund managers exists, it has steadily weakened over time.

\section{A Model of VC Emergence Incorporating Coproduction}

We advance the literature by showing how public and private sector actors co-produced a VC industry in South Africa. Our analysis also shows the centrality of coproduction to the industry's emergence. This process suggests an alternative to the simultaneity model for explaining VC's emergence in WIEs. Embeddedness between these actors has been weakened since 1999, reflecting in part the government's contradictory small business development and innovation policies, and the unintended consequences of BEE.

Our findings suggest an alternative model of VC emergence, as depicted in Figure 3. In this sequential model combining two life-cycle processes (simultaneity and the VC cycle) and one teleological process (coproduction), simultaneity conditions must be satisfied before the coproduction process can be generated. In other words, government investors and fund managers cannot productively cooperate to cause VC emergence, until essential preconditions-pools of capital, specialized financial institutions, and entrepreneurs-are all available in sufficient quantities to justify such cooperation. In turn, coproduction must be operating before the VC cycle can become self-sustaining, primarily because the "equity gap" cannot be filled through market mechanisms. Government investors and fund managers, working together, fill this gap in this model. 


\section{Implications for Policy or Program Development}

Policymakers have focused to date on improvements in the enabling environment in their attempts to jumpstart national VC industries. Our results suggest that, while these changes may be necessary, they are unlikely to be sufficient to sustain active VC industries over time. Instead, the possibility that VC emergence may be in part driven by a teleological process in which coproduction plays a central role suggests that governments and fund managers must focus more efforts on developing cooperative relationships based on shared interests in seeing the emergence of VC.

How might this cooperation be improved or, to put it in theoretical terms, how can additional social capital of this nature be generated between these actors? First, it seems reasonably clear that the dramatic transformations associated with the fall of apartheid will have diminishing ripple effects over time. These transformations have played a central role in testing the ties between government investors and fund managers, but more recent policy changes have become more incremental and, therefore, less likely to disrupt social relations between the government and fund managers. Therefore, the passage of time could lead to a higher degree of trust between government and fund managers.

Second, it seems possible for government to engineer the creation of social capital (Field 2003). Education helps people to build social skills and engage in shared norms and rules (Fukuyama 2001), although much of the learning associated with social capital generation takes place outside formal educational institutions. Mentoring programs have been advocated in recent policy documents from the UK government's Forward Strategy Unit; it is interesting that mentoring was also identified in the 1999 Stillman report as important to VC emergence in 
South Africa. Such mentoring could take place at two levels: between South African and international fund managers and for qualified graduates seeking to enter the VC industry. The latter is currently being explored by the industry in collaboration with the government.

Third, in the South African context it is interesting to note that the ANC depended for decades on the voluntary services of hundreds of thousands of black African and white citizens, yet voluntarism seems quite weak in the country today. Voluntary programs linking private sector individuals with relevant skills to government agencies requiring those skills may be one way to increase the embeddedness between fund managers and government investors, without calling into question the legitimate needs to continue to increase black African participation in government policymaking and implementation.

Fourth, it seems critically important that South African policymakers listen more closely than they have to the key private sector actors involved in implementing innovation policy, including VC fund managers. While South Africa is notable for its very large number of forums that provide for consultation with the citizenry on a variety of issues, it is difficult to claim that economic policymaking in the post-apartheid era has been particularly consultative on issues of innovation. Fund managers, entrepreneurs, and scientists at the working level could have more of a voice in policy matters, and this may contribute to a greater capacity to coproduce VC. Informants have indicated that a forum between the VC industry and government is currently being discussed.

\section{Conclusion}

We developed a new theory of VC emergence based on an exploratory longitudinal case study of the South African VC industry. This theory suggests that emergence occurs as a 
composite of three processes, two of which (simultaneity and the VC cycle) are life cycle in nature and the third (coproduction) is a purposeful, teleological process. Most theories of organizational change and development are also composites of two or more process theory types (Van de Ven and Poole 1995). We hope to study how other similar conceptual frameworks were empirically validated, initially focusing on better understanding the interactions between the life cycle and teleological parts of our model.

Further empirical study of our model in economies where VC remains nascent or has only recently emerged and/or different legal origin environments may offer additional avenues for clarifying the model's details. We will be shortly initiating a longitudinal case study in Botswana to address the former, while we plan case studies in Morocco and Tunisia in the near future to examine the robustness of our model in French legal origin countries. 


\section{References}

Aldrich, H. and M. Ruef (2006). Organizations Evolving. London: Sage.

Allison, G. (1971). Essence of Decision: Explaining the Cuban Missile Crisis, New York: HarperCollins.

Armour, J. and D. Cumming, D. (2003). "The Legal Road to Replicating Silicon Valley," unpublished working paper.

Bent, N., K. Williams, and E. Gilbert (2004). "The Syndication of Private Equity Investments in South Africa," South African Journal of Business Management, 35: 39-48.

Black, B. and R. Gilson (1997). "Venture Capital and the Structure of Capital Markets: Banks versus Stock Markets," unpublished working paper.

Brown, L.D. and D. Ashman (1996). "Participation, Social Capital, and Intersectoral Problem Solving: African and Asian Cases," World Development, 24: 1467-1479.

Bruner, J. (1986). Actual Minds, Possible World. Cambridge, Mass.: Harvard University Press.

Brunt, L. (2006). "Legal Origins, Colonial Origins, and Economic Growth: Evidence from a Natural Experiment," unpublished working paper.

Capgemini and Merrill Lynch (2007). World Wealth Report, Paris: Cap Gemini.

Davidson, P. and B. Honig (2003). "The Role of Social and Human Capital among Nascent Entrepreneurs," Journal of Business Venturing, 18: 301-31.

De Kiewiet, C.W. (1960). A History of South Africa Social \& Economic. London: Oxford University.

Desai, M. and K. Luchs (2006). “Finance in Weak Institutional Environments," Boston, Mass.: Harvard Business School.

Dommisse, E. (2005). Anton Rupert. Cape Town, South Africa: Tafelberg.

Dossani, R. and M. Kenney (2002). "Creating an Environment for Venture Capital in India," World Development, 30: 227-253.

Eriksson, P. and A. Kovalainen (2008). Qualitative Methods in Business Research. Thousand Oaks, Calif.: Sage. 
Evans, P. (1996). “Government Action, Social Capital, and Development: Reviewing the Evidence on Synergy," World Development, 24: 1119-1132.

Feinstein, C. (2005). An Economic History of South Africa. Cambridge, United Kingdom: Cambridge University.

Field, J. (2003). Social Capital. Abingdon, United Kingdom: Routledge.

Fukuyama, F. (2001). "Social Capital, Civil Society, and Development," Third World Quarterly, 22: 7-20.

Gifford, S. (1997). "Limited Attention and the Role of the Venture Capitalist," Journal of Business Venturing, 12: 459-482.

Gilson, R. (2003). "Engineering a Venture Capital Market: Lessons from the American Experience," Stanford Law Review, 55: 1067-1103.

Gompers, P. (1995). “Optimal Investment, Monitoring, and the Staging of Venture Capital," Journal of Finance, 50: 1461-1489.

Gompers, P. and J. Lerner (2000). The Venture Capital Cycle. Cambridge, Mass.: MIT.

Granovetter, M. (1992). "Economic Institutions as Social Constructions: a Framework for Analysis," Acta Sociologica, 35: 3-11.

Gumede, W.M. (2005). Thabo Mbeki and the Battle for the Soul of the ANC. Cape Town, South Africa: Zebra.

Hirsch, A. (2005). Season of Hope: Economic Reform under Mandela and Mbeki. Scottsville, South Africa: University of KwaZulu-Natal.

HM Treasury and Small Business Service (2003). Bridging the Finance Gap: Next Steps in Improving Access to Growth Capital for Small Business, London: HM Treasury and Small Business Service.

Jensen, M. and W. Meckling (1976). "Theory of the Firm: Managerial Behavior, Agency Costs, and Ownership Structure," Journal of Financial Economics, 3: 305-360.

Jovanovic, B. and G. MacDonald (1994). "The Life Cycle of a Competitive Industry," Journal of Political Economy, 102: 322-347.

Karsai, J., M. Wright, and I. Filatotchev (1997). "Venture Capital in Transition Economies: The Case of Hungary," Entrepreneurship Theory and Practice, 21: 93-110. 
Kenney, M., M. Haemmig, and W.R. Goe (2007), "The Globalization of the Venture Capital Industry," unpublished working paper.

Kenney, M. and K. Han (2002). "Venture Capital Industries in East Asia," unpublished working paper prepared for the World Bank.

KPMG and Southern Africa Venture Capital and Private Equity Association (2000-2007). Venture Capital and Private Equity Industry Performance, Houghton, South Africa.

Lam, W. (1996). "Institutional Design of Public Agencies and Coproduction: A Study of Irrigation Associations in Taiwan," World Development, 24: 1039-1054.

Langley A. (1999). "Strategies for Theorizing from Process Data," Academy of Management Review, 24: 691-710.

La Porta, R., F. Lopez-de-Silanes, A. Shleifer, and R. Vishny (1998). "Law and Finance," Journal of Political Economy, 106: 1113-55.

Lerner, J. (2002). "When Bureaucrats Meet Entrepreneurs: The Design of Effective 'Public Venture Capital' Programmes," Economic Journal, 112: F73-F84.

Lerner, J., D. Moore, and S. Shepherd (2005). A Study of New Zealand's Venture Capital Market and Implications for Public Policy. Report to the New Zealand Ministry of Research Science and Technology.

Maas, G. and M.D. Herrington (2007). Global Entrepreneurship Monitor: South Africa Report 2006. Cape Town, South Africa: University of Cape Town Graduate School of Business.

Maula, M. and G. Murray (2003). Finnish Industry Investment Ltd: An International Evaluation, Helsinki: Finnish Ministry of Trade and Industry.

Maula, M., G. Murray, and M. Jääskeläinen (2007). Public Financing of Young Innovative Companies in Finland. Helsinki: Finnish Ministry of Trade and Industry.

North, D. (1990). Institutions, Institutional Change and Economic Performance. New York: Cambridge University Press.

Organization of Economic Cooperation and Development (2006). "South Africa" in African Economic Outlook 2006, Paris: OECD.

Ostrom, E. (1996). "Crossing the Great Divide: Coproduction, Synergy, and Development," World Development, 24: 1073-1087. 
Pollock, T., J. Porac, and J. Wade (2004). "Constructing Deal Networks: Brokers as Network Architects in the U.S. IPO Market and Other Examples," Academy of Management Review, 29: 50-72.

Rodrik, D. (2006). “Understanding South Africa's Economics Puzzles," Cambridge, Mass.: National Bureau of Economic Research.

Sherwin, H. (2008). Letter to Zelna Jansen, Committee Secretary, Portfolio Committee on Science \& Technology, South African Parliament.

Stillman, R.D., J. Sunderland, L. Heyl, and H. Swart (1999). A Venture Capital Programme for South Africa: Study and Recommendations. Arlington, Virginia: Nathan Associates.

Thompson, J. and S-M. Choi (2002). "Risk Capital in OECD Countries: Recent Developments and Structural Issues," Financial Market Trends, 82: 59-102.

Van de Ven, A. (2007). Engaged Scholarship: A Guide for Organizational and Social Research. New York: Oxford University Press.

Van de Ven, A. and M. Poole (1995). "Explaining Development and Change in Organizations," Academy of Management Review, 20: 510-540.

Van de Ven, A., H. Sapienza, and J. Villanueva (2007). "Entrepreneurial Pursuits of Self- and Collective Interests," Strategic Entrepreneurship Journal, 1: 353-370.

Vernon, R. (1966). "International Investment and International Trade in the Product Cycle," The Quarterly Journal of Economics, 80: 190-207.

Woolcock, M, and D. Narayan (2000). "Social Capital: Implications for Development Theory, Research, and Policy," The World Bank Research Observer, 15: 225-49. 
Table 1: Evolution of South African Private Equity and Venture Capital Industries

\begin{tabular}{|c|c|c|c|c|c|c|c|}
\hline Year & $\begin{array}{c}\text { Funds Under } \\
\text { Management } \\
\text { (Rands } \\
\text { billion) }\end{array}$ & $\begin{array}{c}\text { Funds Under } \\
\text { Management } \\
\text { (USD) }\end{array}$ & $\begin{array}{c}\text { Captives- } \\
\text { Government } \\
\text { (amount in } \\
\text { Rands } \\
\text { billion, } \\
\text { Based on year-end } \\
\text { exchange rates on } \\
\text { oanda.com }\end{array}$ & $\begin{array}{c}\text { Total } \\
\text { Investments } \\
\text { funds) } \\
\text { year during } \\
\text { billion) }\end{array}$ & $\begin{array}{c}\text { \% Seed } \\
\text { made } \\
\text { during } \\
\text { year }\end{array}$ & $\begin{array}{c}\text { \% } \\
\text { Startup } \\
\text { and } \\
\text { Early } \\
\text { Stage } \\
\text { made } \\
\text { during } \\
\text { year }\end{array}$ & $\begin{array}{c}\text { Seed, startup, } \\
\text { and early } \\
\text { stage } \\
\text { investments } \\
\text { (Rands } \\
\text { billion) }\end{array}$ \\
\hline 2000 & 34.7 & 4.6 & $8.3(4)$ & 3.5 & 10 & 15 & .875 \\
\hline 2001 & 35.9 & 3.0 & $7.1(5)$ & 2.4 & 1 & 11 & .288 \\
\hline 2002 & 37.0 & 4.3 & $6.2(5)$ & 3.5 & 2 & 23 & .875 \\
\hline 2003 & 39.3 & 5.9 & $5.2(8)$ & 4.3 & 1 & 11 & .516 \\
\hline 2004 & 39.7 & 7.0 & $5.8(6)$ & 6.5 & 0 & 6 & .39 \\
\hline 2005 & 42.5 & 6.7 & $7.0(4)$ & 4.5 & 0 & 11 & .495 \\
\hline 2006 & 56.2 & 8.1 & $10.1(4)$ & 6.0 & 1 & 16 & 1.02 \\
\hline
\end{tabular}

Sources: KPMG and SAVCA (2000-7), oanda.com for FX rates

Table 2: IDC VC Funds

\begin{tabular}{|c|c|c|}
\hline Fund & $\begin{array}{c}\text { Total Funds Under } \\
\text { Management (Rand } \\
\text { millions) }\end{array}$ & $\begin{array}{c}\text { IDC Investment (Rand } \\
\text { millions) }\end{array}$ \\
\hline Phase I (2000-1) & 100 & 75 \\
\hline Argil & 160 & 75 \\
\hline Archway II & 150 & 75 \\
\hline Vantage & 140 & 75 \\
\hline Horizon & 80 & 20.08 \\
\hline Bioventures & & 112 \\
\hline Phase II (post 2001) & 563 & 100 \\
\hline New Africa Mining & 200 & 12 \\
\hline NEF Ventures Trust & 83 & 50 \\
\hline Msele Nedventures & 125 & $\mathbf{5 9 4}$ \\
\hline Women Private Equity Fund & $\mathbf{1 5 9 6}$ & \\
\hline Total & & \\
\hline
\end{tabular}

Source: Author estimates, IDC Year-end rand/USD exchange rates: 7.54 (2000), 11.97 (2001) 
Figure 1: A Life-Cycle Theory of VC Emergence

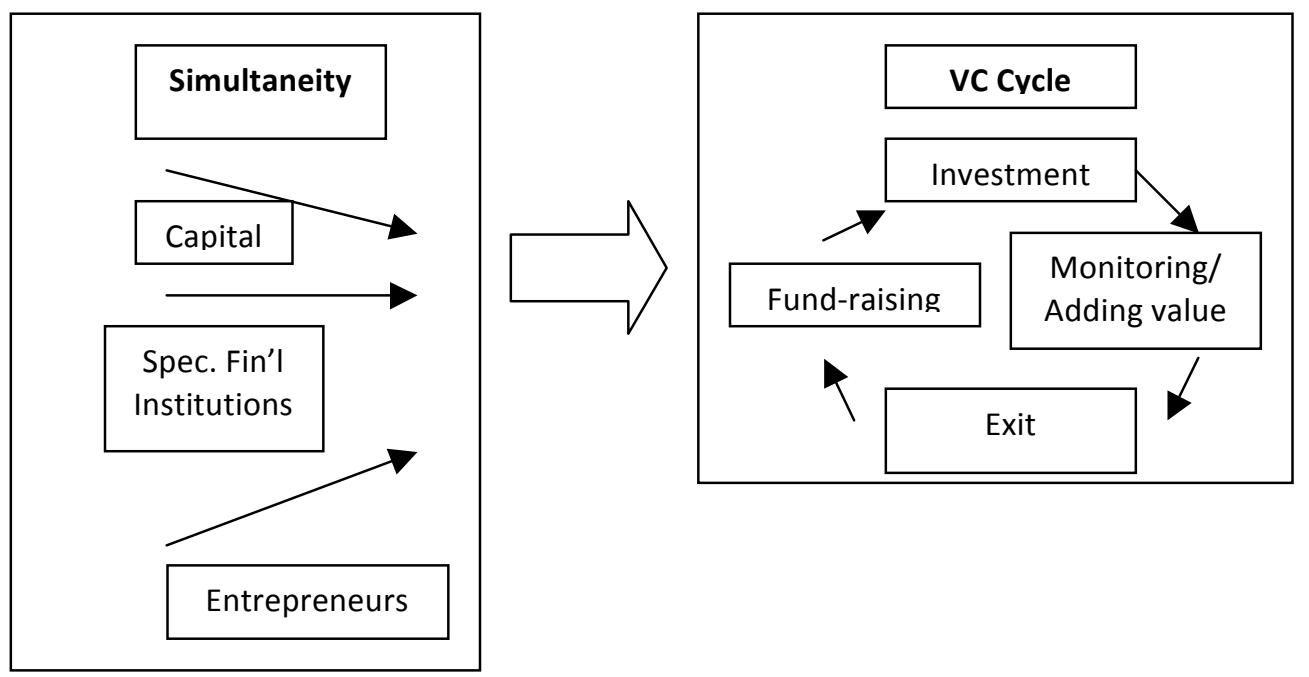

Figure 2: The Coproduction Process (indicative)

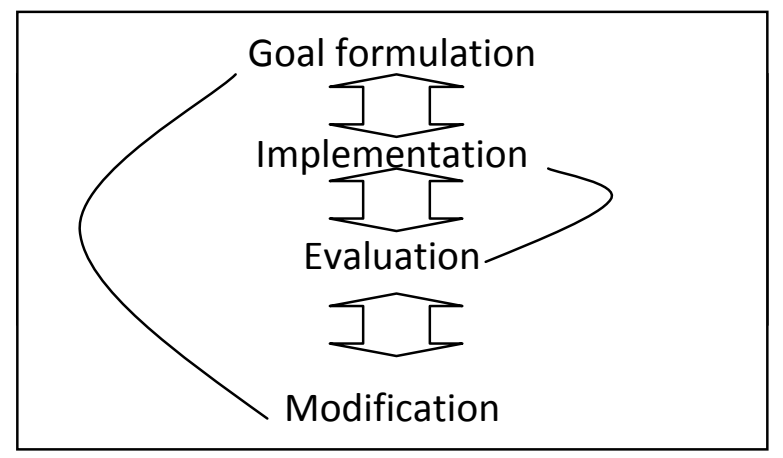


Figure 3: A Theory of VC Emergence Incorporating Coproduction
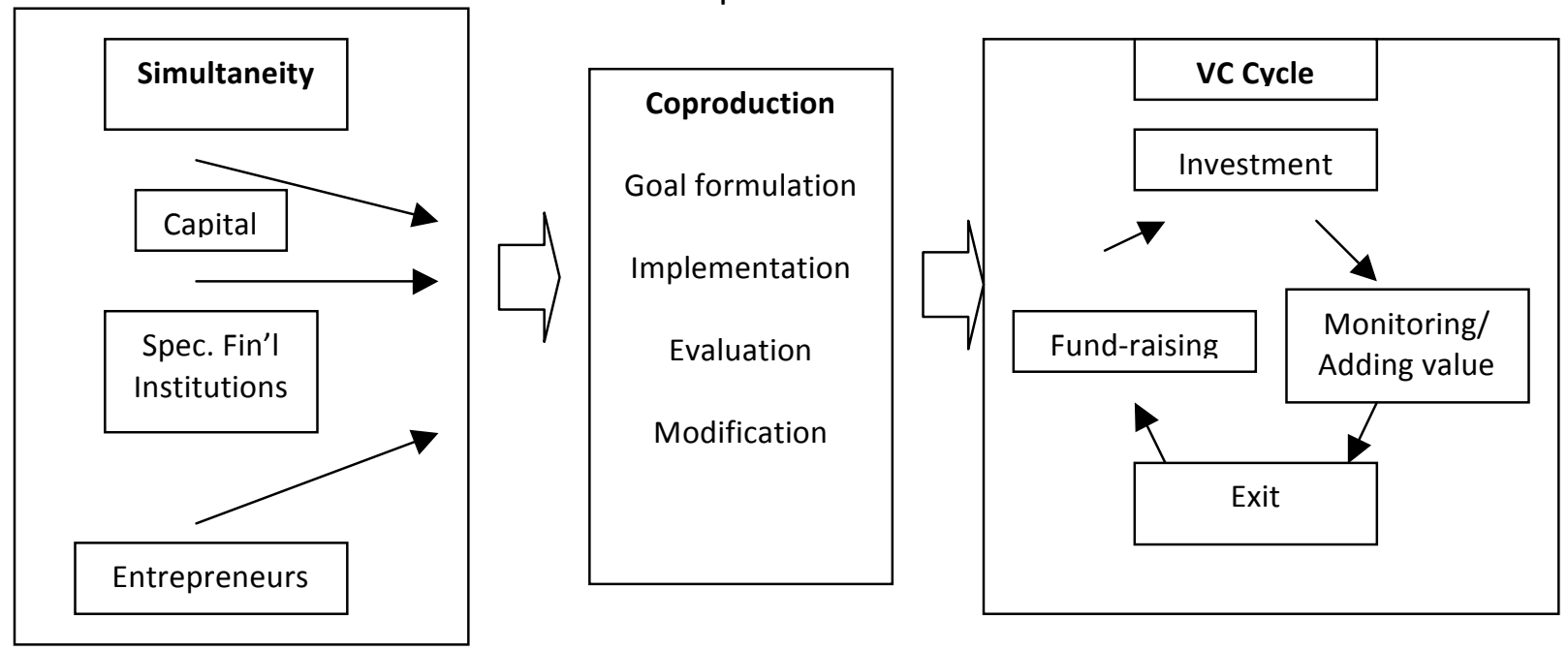